\title{
Identification of squash landraces using UPOV descriptors and morphological traits
}

\author{
E. Mady ${ }^{1,2}$, L. Craker ${ }^{3}$ and A. Helaly ${ }^{1, *}$ \\ ${ }^{1}$ Horticulture Department, Faculty of Agriculture, Al-Azhar University, Cairo, Egypt \\ ${ }^{2}$ Department of Environmental Conservation, University of Massachusetts, Amherst, USA \\ ${ }^{3}$ Stockbridge School of Agriculture, University of Massachusetts, Amherst, USA
}

*Correspondence: alaahelaly@azhar.edu.eg (A. Helaly)

\begin{abstract}
Plant identification and genotyping within a germplasm collection are important elements in planning a breeding program that can improve the development of plants with desirable market characteristics. In the current study, 20 squash (Cucurbita pepo L.) landraces were collected and identified from different areas in Egypt to investigate the plant diversity and genetic variations based on differences in plant morphology and the International Union for Protection of New Varieties of Plants (UPOV) descriptors. A total of 24 quantitative and qualitative morphological differences characterized the genetic variability among genotypes. The demonstrated variability among all the tested landraces suggested a large number of genotypes within the squash lines. The results showed the potential of morphological markers for the identification and assessment of genetic variations among squash landraces and provided a number of choices for planning a successful breeding program to improve squash landraces. The obtained results on the 20 studied genotypes established that the agronomic traits based on morphological traits and UPOV descriptor data provide cost-effective preliminary tools for genotypic varietal characterization and evaluation for breeding purposes. Moreover, the utilization of these neglected local squash landraces and the subsequent improvement can increase the diversity in the food marketplace at the local level and enhance agricultural biodiversity.
\end{abstract}

Keywords: Cucurbita pepo, Landraces, UPOV, Genetic diversity.

\section{INTRODUCTION}

Squash (Cucurbita pepo L.), a member of the Cucurbitaceae family, is one of the most important and popular vegetables in many countries, including Egypt. This crop plant, native to the Americas, was undoubtedly distributed to other continents via transoceanic voyagers during the $15^{\text {th }}$ and $16^{\text {th }}$ century (Whitaker, 1947). The relatively high nutritive and medicinal value of squash, as compared with other vegetable crops, has made squash fruit a traditional favorite vegetable plant in many countries. The constituents of squash include vitamins $\mathrm{A}, \mathrm{C}$, niacin, and folate along with fiber (USDA, 2018), making this plant a suitable dietary source that helps prevent cancers, heart disease, and inflammation problems, such as asthma and arthritis (Balluz et al., 2005). Moreover, as a low-calorie food, summer squash is beneficial in weight loss diets (Hedstrom and Yerxa, 2008).

The annual worldwide value of summer squash is several billion dollars, indicating the significantly high economic value of this vegetable crop as compared with other crops (Paris, 1996). Overall, world squash production during the year 2009 reached 21 million metric tons (Nanasato et al., 2011). The largest producers of summer squash include Turkey,
Italy, Egypt, Spain, U.S.A., and Mexico (Paris, 2008). The cultivated area for squash in Egypt during the 2013/2014 season was 25,050 hectares, producing nearly 444,649 metric tons with an average of 17.75 tons/ha (Economic Affairs Sector, Ministry of Agriculture and Land Reclamation, 2015).

The numerous genotypes, varieties, and cultivars of squash that vary in physical appearance and chemical constituents (Brown et al., 2013; Abd El-Hamed et al., 2015; MartínezValdivieso et al., 2015; Mady, 2016) are cultivated and maintained by local farmers in Egypt, but fruit yields are of poor quality and quite limited in seed production. The growers traditionally save the squash seeds for planting the next year's landrace squash crops with diverse characteristics, scattered across different parts of the country.

Concurrently, domestication became necessary to limit the overcollection of desired species and genotypes that could cause plant extinction (Craker et al., 2015). Selection of improved landraces by the use of plant collections, maintenance, and breeding programs could be expected to help growers secure productivity and enhance fruit quality. The collection, maintenance, and assessment of the genetic diversity of Egyptian summer 
squash landraces could establish breeding programs that would improve the studied landraces or produce new hybrids that meet farm and market demands for disease resistance, growth habits, and high fruit yields of better quality. Detailed studies of the physical, chemical, and genetic characteristics of the collected squash genotypes provide the necessary genes for improvement of plant yield and other desirable characteristics. Knowledge about the magnitude of variation in these genotypes and the relationship of desirable plant characteristics within the yield besides the environmental factors on these plant materials is necessary.

Varietal characterization, based on morphological data, has been used in several studies: Brussels sprouts (Mady, 2008), watermelon (Solmaz and Sari 2009), celery (Helaly et al., 2014), molokhia (Helaly et al., 2017). Biochemical and molecular tools were also used for varietal identification, i.e. celery (Helaly et al., 2015), squash (Mady et al., 2013 \& 2014), summer squash (Xanthopoulou et al., 2015), (Mady, 2016), and Cucurbita pepo accessions (Michael et al., 2019). Plant morphologies reflect the genetic constitution of cultivars and the interaction of the genotype with the environment (Yadav, 2008).

In the current study, genetic variability of squash germplasm in Egypt was examined using morphological markers to assist in parental selection for breeding programs. Squash genotypes can be phenotypically distinguished from one to another by growth habits, such as vegetative structures, flowering dates, yield, and fruit characteristics. Investigators focus on these characteristics to identify and differentiate the various squash genotypes. Genetic characteristics have been added in recent years to complete a full picture of taxonomy by a definitive tool.

On watermelon (Citrullus lanatus), the
UPOV descriptors were used to morphologically characterize 134 accessions of the Turkish genetic resources using the UPOV descriptor list for 56 qualitative characters on seedling, plant, leaf, flower, fruit, and seed. Additionally, 22 quantitative characters were also measured. The studied accessions showed a great variation for most of the morphological traits. However, the geographical origin was not a great source for grouping (Solmaz and Sari, 2009).

The present study was conducted to assess the morphological variability within a set of 20 squash landraces collected from Egypt to plan an effective breeding program for the improvement of squash by selecting a few genotypes and building up new varieties to meet the market demands. For this objective, evaluation of the morphological characteristics is essential for establishing this program.

\section{MATERIALS AND METHODS}

To determine the improvement potential of Egyptian squash landraces (Cucurbita pepo, L.), a preliminary study tested 20 Egyptian squash landraces for homogeneity in two growing seasons, 2009 and 2010. Seeds of the 20 squash landraces were collected from various locations in many Egyptian areas representing different climate zones (Table 1 and Figure 1). Seeds of collected squash landraces were sown in a private farm in Beheira Governorate, Egypt on February $10^{\text {th }}$, during the summer growing seasons of 2009 and 2010. Plantings of four replicates were arranged in a randomized complete block design in the field with $40 \mathrm{~cm}$ between plants in nine-meter rows that were 70 $\mathrm{cm}$ apart. Irrigation was applied in furrows while other necessary agricultural activities were done according to the recommendations of the Egyptian Ministry of Agriculture.

\section{Morphological characteristics.}

At 50 days after seeding, plant height was measured from the cotyledonary node to the highest point of the plant. In addition, the number of leaves on the measured plant were counted and leaf area was determined by outlining each leaf on a sheet of millimeter graph paper, on which the squares were counted to represent leaf area in $\mathrm{cm}^{2}$.

\section{Statistical analysis}

All quantitative morphological data were subjected to statistical analysis according to the procedures reported by Snedecor and Cochran (1980). Means of the genotypes were compared using Least Significant Difference (L.S.D) at the $5 \%$ level of probability in the two seasons of the experiment.

\section{Identification using UPOV descriptor lists}

Seeds of 20 squash landraces were sown in separate plastic pots filled with the commercial growing mix (Pro-Mix BX, Pro-Mix Inc., Quakertown, PA, USA) on March 1 1st, in 2012 and in 2013. The seeded pots were placed in a plastic-covered greenhouse at the Stockbridge School of Agriculture, University of Massachusetts, Amherst, USA. All agricultural practices (watering along with weed and insect control) were managed as necessary to maintain optimum plant growth. 
Between March and July in 2012 and 2013, five plants collected from each replicate for observation of UPOV (International Union for the Protection of New Varieties of Plants) descriptors. Selected squash morphological traits designated as descriptors by the International Union for the Protection of New Varieties of Plants (UPOV) we used to identify the tested squash landraces. A total of 21 descriptors were selected from the UPOV guideline TG/119/4 for vegetable marrow and squash (UPOV, 2007) as follows:

\section{Vegetative characteristics} trailing).

Growth habit (bush, semi trailing or

Branching (absent or present).

Degree of branching (very weak, weak, medium, strong or very strong).

Attitude of petiole (erect, erect to semierect, semi-erect to horizontal or horizon-tal).

Stem color (green or partly green and partly yellow).

Intensity of stem green color (very light, light, medium dark or very dark).

Mottling (absent or present).

Tendrils (absent to rudimentary or well developed).

Leaf blade size (very small, small, medium, large or very large).

Incisions (absent to very shallow, shallow, medium, deep or very deep).

Intensity of green color of the blade upper surface (light, medium or dark).

Silvery patches (absent or present).

Relative area covered by silvery patches (very small, small, medium, large or very large).

Petiole length (short, medium or long).

Number of prickles (absent or very few, few, medium, many or very many).

\section{Flower characteristics}

\section{Female flowers}

Ring at inner side of corolla (absent or present).

Color of ring at inner side of corolla (yellow, green, or yellow and green).

Genotypes with green ring at the inner side of corolla: Intensity of green color (weak, medium, or strong).

\section{Male flowers}

Ring at inner side of corolla (absent or present).

Color of ring at inner side of corolla (Yellow, green, or yellow and green).

Genotypes with green ring at inner side of corolla: Intensity of green color of the ring (Weak, medium, or strong).

\section{RESULTS}

The comparison and mutual relationships among the investigated 20 squash landraces were achieved by measuring a number of attributes which comprise the vegetative growth and flowering stages. Moreover, the genetic identification by fingerprinting of all the studied genotypes was implemented on either the leaves or seeds that was done by applying the suitable techniques.

\section{Identification based on plant characteristics:}

\section{Vegetative characteristics}

Accumulated data for each of the squash characteristics of the twenty landraces were combined statistically for the two growth seasons.

\section{Plant height}

Plant height of the squash genotypes in the two seasons of 2009 and 2010 were combined and illustrated in Table (2). From the obtained results, it is obvious that the genotype Matruh 1 scored the longest significant values for the plant height while Gharbia 1 produced the shortest one among the studied genotypes.

\section{Leaf number}

The data on the leaf number per plant of the various squash landraces represented in combined analysis in 2009 and 2010 seasons are shown in Table (2). The previous figures clearly indicate that the largest leaf number per plant was produced from the genotype Matruh 1 and Alexandria 1 with no significant difference between them while the smallest number produced from Sohag genotype.

\section{Leaf area}

The leaf area records of the studied squash landraces in a combined analysis in 2009 and 2010 seasons are demonstrated in Table (2). The figures clearly differ in the leaf area of the various squash genotypes. The widest leaf area resulted from Giza 1 with no significant difference with Alexandria 1 while Sohag significantly recorded the narrowest one. 


\section{Identification using UPOV descriptor lists}

The studied squash landraces were
evaluated for the morphological characterization based on UPOV descriptor list (UPOV, 2007). A total of 21 morphological characteristics were assessed and tabulated (Tables 3, 4, 5, 6, 7 and 8). The tabulated data on the differences in morphological characteristics among the studied squash genotypes revealed considerable variations (Table 3). The obtained results on the 20 squash landraces clearly show that the bush growth habit was observed in 9 landraces (45\%), semi-trailing in 10 landraces $(50 \%)$ and only one landrace was trailing $(5 \%)$. The studied squash landraces were distributed into branched 11 landraces (55\%) and the nonbranched ones were 9 landraces (45\%). In the branched landraces, the degree of branching was very weak in one landrace (5\%), weak in 5 landraces $(25 \%)$, medium in 4 landraces $(20 \%)$ and strong in one landrace.

Concerning the stem color, the majority of the studied landraces $15(75 \%)$ had completely green stem color while the remaining landraces $5(25 \%)$ stem (Table 4$)$. The intensity of the green color of the stem was very light in 3 landraces $(15 \%)$, light in 4 landraces $(20 \%)$, medium in 4 landraces $(20 \%)$ and dark in 9 landraces $(45 \%)$. Only two landraces showed the mottling in their stems. For the tendrils, the majority of the studied landraces 15 (75\%) produced well developed tendrils while this trait was absent in the remaining landraces. Concerning the leaf blade size, two landraces had small blades (10\%), 7 landraces had medium (35\%), 6 landraces had large blades $(30 \%)$ and 5 landraces had very large blades (25\%).

The leaf incisions were absent or very shallow in 4 landraces (20\%), shallow in 7 landraces $(35 \%)$, medium in 6 landraces $(30 \%)$, deep in 1 landrace (5\%) and very deep in 2 landraces (10\%) (Table 5). The leaf green color intensity was light in 1 landrace (5\%), medium in 12 landraces $(60 \%)$, dark in 7 landraces $(35 \%)$. Only 3 landraces developed silvery patches on their leaf blades $(15 \%)$ while this character was absent in the remaining landraces. Within the 3 landraces with silvery patches, the relative areas covered by these patches was small in 1 landrace $(5 \%)$, medium in 1 landrace $(5 \%)$ and large in 1 landrace (5\%).

Petioles were short in 7 landraces (35\%), medium in 5 landraces (25\%) and long in 8 landraces (40\%) (Table 6). Furthermore, the petioles were erect in 4 landraces (20\%), erect to semi-erect in 7 landraces (35\%), semi-erect in 3 landraces (15\%), and semi-erect to horizontal in 6 landraces $(30 \%)$. There were no or very few prickles in 1 landrace $(5 \%)$, few in 8 landraces $(40 \%)$, medium in 4 landraces (20\%), many in 6 landraces $(30 \%)$ and very many in 1 landrace (5\%) (Table 6).

Most landraces had a ring at the inner side of the corolla of their female flowers, 14 landraces $(70 \%)$ while the rest of landraces, 6 (30\%) were absent. This ring was yellow in 5 landraces $(25 \%)$ or green in 9 landraces $(45 \%)$ (Table 7). Regarding the male flower, 13 landraces $(65 \%)$ developed a ring at the inner side of their corollas. This ring was yellow in 4 landraces $(20 \%)$ and green in 9 landraces $(45 \%)$ (Table 8).

From the obtained results using the UPOV descriptors, the examined squash landraces can be characterized in the following descriptions:

Alexandria 1 can be described with the bush growth habit, very weak branching, erect to semi-erect long petioles with many prickles, very large leaf blades without or with very shallow incisions, dark green color of the leaf upper surface, no silvery patches, complete medium green stem, no mottling, well developed tendrils, no ring at the inner side of the female flower corolla and light green ring at the inner side of the male flower corolla.

Alexandria 2 is characterized with semitrailing growth habit, medium branching, erect to semi-erect short petioles with a medium number of prickles, medium leaf size with medium incisions, medium green color of the leaf upper surface, no silvery patches, complete dark green stem, no mottling, well developed tendrils and no ring at the inner side of the female flower corolla and yellow ring at the inner side of the male flower corolla.

Aswan has semi-trailing growth habit, medium branching, erect to semi-erect medium petioles with many prickles, very large leaf blades without or with very shallow incisions, dark green color of the leaf upper surface, no silvery patches, complete medium green stem color, no mottling, well developed tendrils and weak green ring at the inner side of the male and female flower corollas.

Beheira 1 has semi-trailing growth habit, weak branching, semi- erect short petioles with a few prickles, large leaf blades with medium incisions, light green color of the leaf upper surface, no silvery patches, partly dark green and partly yellow stem color, no mottling, well developed tendrils and yellow ring at the inner side of the male and female flower corolla. 
Beheira 2 is characterized with bush growth habit, no branching, semi-erect to horizontal long petioles with a very large number of prickles, very large leaf blades without or with very shallow incisions, medium green color of the leaf upper surface, relatively small areas covered by silvery patches, complete light green stem color, no mottling, well developed tendrils, medium green ring at the inner side of the female flower corolla and no ring at the inner side of the male flower corolla.

Beheira 3 is characterized with semi-trailing growth habit, no branching, semi-erect to horizontal long petioles with a few prickles, medium leaf blades with medium incisions, medium green of the leaf upper surface, no silvery patches, partly very light green and partly yellow stem, no mottling, well developed tendrils and no ring at the inner side of the male or female flower corolla.

Beheira 4 is characterized by semi-trailing growth habit, strong branching degree, erect short petioles with many prickles, small leaf blades with very deep incisions, dark green color of the leaf upper surface, no silvery patches, partly light green and partly yellow stem, some mottling, well developed tendrils, medium green ring at the inner side of the female flower corolla and no ring at the inner side of the male flower corolla.

Dakahlia 1 can be characterized by the bush growth habit, no branching, erect to semi-erect long petioles with many of prickles, large leaf blades with medium incisions, dark green color of the leaf upper surface, no silvery patches, complete dark green stem color, no mottling, well developed tendrils and light green ring at the inner side of the female flower corolla and weak green ring at the inner side of the male and female flower corollas.

Dakahlia 2 is characterized by the bush growth habit, no branching, semi-erect to horizontal short petioles with a few prickles, leaf blades with deep incisions, dark green color of the upper surface leaves, relatively large areas covered by silvery patches, complete dark green stem, no mottling, well developed tendrils, and strong green ring at the inner side of the male and female flower corollas.

Dakahlia 3 has bush growth habit, weak branching, semi-erect medium petioles without or with a very few prickles, large leaf blades with shallow incisions, medium green color of the leaf upper surface, no silvery patches, complete medium green stem, no mottling, well developed tendrils and medium green ring at the inner side of the female flower corolla and no ring at the inner side of the male flower corolla.

Eskandarani is characterized by the semi trailing growth habit, no branching, erect to semi-erect long petioles with a medium number of prickles, large leaf blades with medium incisions, medium green color of the leaf upper surface, no silvery patches, complete dark green stem color, some mottling, well developed tendrils, yellow ring at the inner side of the female flower corolla and medium green ring at the inner side of the male flower corolla.

Gharbia 1 has bush growth habit, no branching, erect to semi-erect medium petioles with many prickles, medium sized leaves with shallow incisions, medium green color of the upper surface of the leaves, no silvery patches, complete dark green stem color, no mottling, absent to rudimentary tendrils and dark green ring at the inner side of the male and female flower corollas.

Gharbia 2 can be described with bush growth habit, no branching, erect medium petioles with a medium number of prickles, very large leaf blades without or with very shallow incisions, medium green color of the leaf upper surface, no silvery patches, partly very light green and partly yellow stem color, no mottling, well developed tendrils, no ring at the inner side of the female flower corolla and yellow ring at the inner side of the male flower corolla.

Gharbia 3 can be identified with semitrailing growth habit, weak branching, semierect to horizontal short petioles with many prickles, small leaf blades with shallow incisions, medium green color of the leaf upper surface, no silvery patches, complete light green stem, no mottling, without or with rudimentary tendrils, medium green ring at the inner side of the female flower corolla and no ring at the inner side of the male flower corolla.

Giza 1 can be portrayed with the semitrailing growth habit, no branching, erect long petioles with many of prickles, very large leaf blades with shallow incisions, medium green color of the upper leaf surface of the leaves, no silvery patches, complete light green stems, no mottling, well developed tendrils, yellow ring at the inner side of the female flower corolla and weak green ring at the inner side of the male flower corolla.

Giza 2 is characterized by semi-trailing growth habit, medium branching, erect to semierect medium petioles with a few prickles, large leaf blades with 
shallow incisions, complete medium green stem, no mottling, absent to rudimentary tendrils, medium green color of the leaf upper surface, no silvery patches, dark green ring at the inner side of female flower corolla and light green ring at the inner side of the male flower corolla.

Matruh 1 is characterized by semi-trailing growth habit, weak branching, semi-erect short petioles with a few prickles, medium leaf blades with shallow incisions, no silvery patches, complete dark green stem, no mottling, well developed tendrils and yellow ring at the inner side of male and female flower corollas.

Matruh 2 can be identified with the bush growth habit, weak branching, erect short petioles with a medium number of prickles, medium leaf blades with shallow incisions, medium green color of the leaf upper surface, no silvery patches complete dark green stem, no mottling, absent to rudimentary tendrils, no ring at the inner side of the female flower corolla and yellow ring at the inner side of the male flower corolla.

North Sinai 1 can be portrayed with the trailing growth habit, medium branching, semierect to horizontal long petioles with a few prickles, large leaf blades with medium incisions, medium green color of the leaf upper surface, no silvery patches, partly very light green and partly yellow stem, no mottling, well developed tendrils, yellow ring at the inner side of the female flower corolla and no ring at the inner side of the male flower corolla.

Sohag has bush growth habit, no branching, semi-erect to horizontal short petioles with a few prickles, medium leaf size with very deep incisions, dark green of the leaf upper surface, relatively medium areas covered by silvery patches, complete dark green stem, no mottling, absent or rudimentary tendrils, medium green ring at the inner side of female flower corolla and no ring at the inner side of male flower corolla.

\section{DISCUSSION}

If there is a look towards the previous results, it is easy to notice that the aforementioned investigated squash genotypes varied in their vegetative characteristics. This, however, may be related to many reasons which is the subject of our discussion. Physiologically speaking, the growth of squash, as the other horticultural plants, is a complex process of progressive development resulting in more cells, greater size, larger yield, increase the push towards maturity and increased specialization of plant parts. Basic processes which plants depend on for growth are photosynthesis for food supply, respiration for energy release, assimilation for food utilization, absorption for raw materials, transpiration for upward flow of water and translocations for movement of manufactured food (Wien, 1997). Moreover, the plant is more than the sum of its physiological processes. The orderly cycle of development that the whole plant undergoes involves complex patterns of changes in cells, tissues and organs (Bakry, 2005).

Our results showed that there were genetic differences in the studied characteristics of the vegetative growth among the examined genotypes. However, it was noticed in one of the important trials that the variation found in some species for the length of stem depended on different chromosomes, position of the centromere and occurrence of satellites (Robinson and Decker-Walters, 1997). Furthermore, for general knowledge in this field, an updated gene list for one of the major cucurbit crops is published each year and nearly one hundred major genes controlling different aspects of Cucurbita biology that have been described (Paris and Padley Jr, 2014). For example, the bush habit which results from the reduced length of internodes in Cucurbita pepo, L. is controlled by a single gene $(b u)$ (DeckerWalters and Munger, 1963; Wu et al., 2007). The $(b u)$ bush type is dominant to the vine type $(b u)$. Microscopic observations show that the bushy feature is due to cell elongation inhibition rather than a reduction in cell number $(\mathrm{Wu}$ et al., 2007). Consequently, the landraces with long plants such as Matruh 1 and Alexandria 1 could be attributed to the lack of $b u$ gene in the dominant form while the other landraces i.e. Gharbia 1 and the shortest plants probably contained this gene.

Twenty squash landraces collected from several locations in Egypt were investigated for plant, leaf and flower characteristics according to selected UPOV descriptors. The studied characteristics of the various landraces showed a wide range of diversity. Our results are consistent with that of Solmaz and Sari (2009), Aruah et al. (2010), Mladenovic et al. (2014) and Kalyanrao et al. (2016).

Concerning the growth habit, it is controlled by the gene $B u$ which is dominant to the vine habit $b u$ (Paris and Padley Jr, 2014). The green base of petals is governed by the $G b$ gene which is dominant to the plant with no band (Dutta and Nath, 1972). On squash, leaf silvery trait is possibly under genetic control (Kasrawi, 1995). 
Of all the species of the Cucurbitaceae, Cucurbita pepo is perhaps the most polymorphic one and one of the most polymorphic of the plant kingdom (Naudin, 1856). Moreover, a large diversity in 17 morphological and horticultural traits among the tested summer squash landraces was observed (Kasrawi, 1995). In our experiment, the small number of vine types (only a single landrace was observed) in the collection could be attributed to the replacement of vine landraces by the modern bush cultivars. The growth habit of squash is of great importance and growers replaced the bush type with the vine type for intensive culture.

All the morphological markers that have been used in this study were proved to be useful and showed some polymorphism among the tested squash genotypes. So, the use of UPOV descriptors based on morphological traits can facilitate and help in the accurate separation in a short time between any seeds of different genotypes, accessions, cultivars, varieties, species, and texa as well as their use in the field inspection for plant breeders.

\section{CONCLUSION}

In this study, on the 20 squash landraces, morphological characterization using UPOV descriptors and some agronomic traits were done to highlight the diversity of specific traits of these local accessions. Furthermore, our results reveal that all 20 local accessions are quite diverse in the studied traits. Therefore, the results reported could be helpful in the parental selection and first step to initiate a breeding program to improve these local landraces. Thus, the selected morphological traits and UPOV descriptors can facilitate and help in the accurate and expeditious separation between any seeds of different genotype, accessions, cultivars, varieties, species, and texa along with their usage in field inspection for breeding purposes. Furthermore, the exploitation of these neglected local landraces and the subsequent improvement can help diversify the food market at the local level and enhance the agrobiodiversity.

\section{ACKNOWLEDEMENT}

The study was partially supported by the Egyptian Cultural Affairs and Mission Sector, Ministry of Higher Education. The authors are grateful to Prof. Dr. M. El-Danasoury, Dept. of Biochemistry, Faculty of Agriculture in Cairo, Al-Azhar University, Egypt for his valuable advice in planning and designing this study.

\section{REFERENCES}

Abd El-Hamed, K.E., Elwan, M.W., Mohamed, F.H., 2015. Genetic diversity and relationship in squash using morphological, chemical and molecular analyses. Int. J. Hort., 5 (12), 1-10.

Aliyu, L., 2003. Performance of some guna melon (Citrullus lanatus Thunb Mansf.) varieties at Samaru. Crop Res. Hisar, 25 (2), 266-271.

Aruah, C.B., Uguru, M.I., Oyiga, B.C., 2010. Variation among some Nigerian Cucurbita landraces. Afr. J. Plant Sci., 4 (10), 374-386.

Bakry, A.M., 2005. Identification studies on Egyptian cowpea by fingerprinting technique. Ph.D. Thesis, Faculty of Agriculture, Al-Azhar University, Cairo, Egypt.

Balluz, L.S., Okoro, C.A., Bowman, B.A., Serdula, M.K., Mokdad, A.H., 2005. Vitamin or supplement use among adults, behavioral risk factor surveillance system, 13 states, 2001. Public Health Rep., 120 (2), 117-123.

Brown, C.H., Luedeling, E., Wichmann, S., Epps, P., 2013. The paleobiolinguistics of domesticated squash (Cucurbita spp.). Explorations in Ethnobiology: The Legacy of Amadeo Rea. ed. M. Quinlan and MD Lepofsky, pp.132-161.

Craker, L.E., Mady, E., Emami, Z., 2015. Understanding the role of medicinal and aromatic plants in a trendy society. Book of Abstracts of International scientific conference: New trends in the ecological and biological research, 9-11 September, University of Prešov, Prešov, Slovak Republic. p:15.

Decker-Walters, D., Munger, H.M., 1963. Morphology of the bush and vine habits and the allelism of the bush genes in Cucurbita maxima and C. pepo squash. Proc. Am. Soc. Hort. Sci., 82, 370-377.

Dutta, L.P., Nath, P., 1972. Inheritance of flower and fruit characters in squash, Cucurbita pepo L. Intl. $3^{\text {rd }}$ Symp. SubTrop. Trop. Hort., pp. 69-74.

Hedstrom, N., Yerxa, K., 2008. Vegetables and Fruits for Health: Zucchini and Summer Squash. Bulletin No. 4257. The University of Maine. https://extension.umaine.edu/ publications/4257e/ Accessed on: 2/15/2019.

Helaly, A., Alkharpotly, A., Mady, E., Craker, L.E., 2017. Characterization of four molokhia (Corchorus olitorius) landraces by morphology and chemistry. J. Med. Active Plants, 5 (2), 1-6.

Helaly, A.A., El-Refy, A., Mady, E., Mosa, K.A. Craker, L., 2014. Morphological and molecular analysis of three celery accessions. J. Med. Active Plants, 2 (3), 27-32.

Helaly, A.A., Baek, J.P., Mady, E., Eldekashy, M.H.Z., Craker, L., 2015. Phytochemical analysis of some celery accessions. J. Med. Active Plants, 4 (1), 1-7.

Kalyanrao, K., Tomar, B.S., Singh, B., Aher, B.M., 2016. Morphological characterization of parental lines and cultivated genotypes of bottle gourd (Lagenaria siceraria). Ind. J. Agric. Sci., 86 (1), 65-70.

Kasrawi, M.A., 1995. Diversity in landraces of summer squash from Jordan. Genet, Resour. Crop Evol., 42, 223-230.

Mady, E.A., Helaly, A., Shanan, S.A., Craker, L.E. 2014. Phylogenetic analysis of Cucurbita pepo using molecular markers. Int, Symposium on Medicinal Plants and Natural Products. Acta Hortic., 1030, 139-142.

Mady, E.A., Helaly, A.A., El-Hamd, A., Abdou, A., Shanan, S.A., Craker, L.E., 2013. Genetic diversity assessment of summer squash landraces using molecular markers. Mol. Biol. Rep., 40 (7), 4269-4274. 
Mady, E.A. 2008. Studies on growth, production, and salt tolerance of Brussels sprouts (Brassica oleracea var. gemmifera Zenk.). M.Sc. Thesis, Horticulture Dept., Faculty of Agriculture, Al-Azhar University, Cairo, Egypt.

Mady, E.A.A., 2016. Identification of some Egyptian squash landraces by fingerprinting technique. Ph.D. Thesis. Hort. Department, Faculty of Agriculture, Al-Azhar University, Cairo, Egypt.

Martínez-Valdivieso, D., Gómez, P., Font, R., Alonso-Moraga, Á., Del Río-Celestino, M., 2015. Physical and chemical characterization in fruit from 22 summer squash (Cucurbita pepo L.) cultivars. LWT-Food Sci.Technol., 64 (2), 1225-1233.

Michael, J.V., Moon, P., Fu, Y., Meru, G., 2019. Genetic diversity among accessions of Cucurbita pepo resistant to Phytophthora crown rot. Hort. Sci., 54 (1), 17-22.

Mladenovic, E., Berenji, J., Ognjanov, V. Ljubojevic, M., Čukanovic, J., Salamun, T., 2014. Genetic diversity in a collection of ornamental squash (Cucurbita pepo L.). Genetika, 46 (1), 199-207.

Nanasato, Y., Konagaya, K., Okuzaki, A., Tsuda, M., Tabei, Y., 2011. Agrobacterium-mediated transformation of kabocha squash (Cucurbita moschata Duch) induced by wounding with aluminum borate whiskers. Plant Cell Rep., 30 (8), 1455-1464.

Naudin, C., 1856. Nouvelles recherches sur les caracteres speciques et les varietes des plantes du genre Cucurbita. Ann. Sci. Nat., Bot.., 6:5-73.

Paris, H.S., 1996. Summer squash: history, diversity, and distribution. Hort. Tech., 6, 6-13.

Paris, H.S. 2008. Summer squash. In: Prohens J, Nuez F (eds) Handbook of Plant Breeding. Vegetables I. Springer, New York, pp. 351-379.

Paris, H.S., Padley Jr, L.D., 2014. Gene List for Cucurbita species, 2014.

http://cuke.hort.ncsu.edu/CGC/cgcgenes/gene14squash. 128.
Robinson, R.W., Decker-Walters, D.S., 1997. Cucurbits (Crop Production Science in Horticulture). Cab International. NY, USA.

Snedecor, G.W., Cochran, W.G., 1980. Statistical methods. Oxford \& J. BH Publishing Com. $7^{\text {th }}$ ed.

Solmaz, I., Sari, N., 2009. Characterization of watermelon (Citrullus lanatus) accessions collected from Turkey for morphological traits. Genet. Resour. Crop Evol., 56 (2), 173188.

UPOV (The International Union for the Protection of New Varieties of Plants) 2007. Descriptors for vegetable marrow and squash (Cucurbita pepo L.). Guidelines for the conduct of tests for distinctness, uniformity and stability. TG/119/4. www.upov.int/edocs/tgdocs/en/tg119.pdf

USDA (U.S. Department of Agriculture) 2018. Agricultural Research Service. Food Data Central. Squash, summer, all varieties, raw (SR Legacy, 170487). https://fdc.nal.usda.gov/fdc-app.html\#/food-details/ 170487/nutrients. Accessed on (2 Jan. 2021).

Whitaker, T.W., 1947. American origin of the cultivated cucurbits. Ann. Mo. Bot. Gard., 34, 101-111.

Wien, H.C., 1997. The physiology of vegetable crops. CAB International. Wallingford Univ. Press. Cambridge, UK. P. 661.

Wu, T., Zhou, J., Zhang, Y., Cao, J., 2007. Characterization and inheritance of a bush-type in tropical pumpkin (Cucurbita moschata Duchesne). Sci. Hort., 114 (1),1-4.

Xanthopoulou, A., Ganopoulos, I., Kalivas, A., NianiouObeidat, I., Ralli, P., Moysiadis, T., Tsaftaris, A., Madesis, P., 2015. Comparative analysis of genetic diversity in Greek gene bank collection of summer squash (Cucurbita pepo) landraces using start codon targeted (SCOT) polymorphism and ISSR markers. Aust. J. Crop Sci., 9 (1), 14-21.

Yadav, R.K., 2008. Seed protein electrophoresis studies in cucurbits. Agric. Rev., 29, 253-496.

Table 1. The squash landraces (Cucurbita pepo, L.) collected from several locations in Egypt.

\begin{tabular}{cccc}
\hline Genotypes & Collection & Genotypes & Collection \\
\hline $\mathbf{1}$ & Alexandria 1 & $\mathbf{1 1}$ & Eskandarani \\
$\mathbf{2}$ & Alexandria 2 & $\mathbf{1 2}$ & Gharbia 1 \\
$\mathbf{3}$ & Aswan & $\mathbf{1 3}$ & Gharbia 2 \\
$\mathbf{4}$ & Beheira 1 & $\mathbf{1 4}$ & Gharbia 3 \\
$\mathbf{5}$ & Beheira 2 & $\mathbf{1 5}$ & Giza 1 \\
$\mathbf{6}$ & Beheira 3 & $\mathbf{1 6}$ & Giza 2 \\
$\mathbf{7}$ & Beheira 4 & $\mathbf{1 7}$ & Matruh 1 \\
$\mathbf{8}$ & Dakahlia 1 & $\mathbf{1 8}$ & Matruh 2 \\
$\mathbf{9}$ & Dakahlia 2 & $\mathbf{1 9}$ & North Sinai \\
$\mathbf{1 0}$ & Dakahlia 3 & $\mathbf{2 0}$ & Sohag \\
\hline
\end{tabular}


Table 2. Plant vegetative characteristics of squash landraces in combined analysis in 2009 and 2010.

\begin{tabular}{cccc}
\hline Landraces & $\begin{array}{c}\text { Plant } \\
\text { Height } \mathbf{( c m )}\end{array}$ & $\begin{array}{c}\text { Leaf } \\
\text { Number }\end{array}$ & $\begin{array}{c}\text { Leaf Area } \\
\left(\mathbf{c m}^{\mathbf{2}}\right.\end{array}$ \\
\hline Alexandria 1 & 96.17 & 28.17 & 442.4 \\
Alexandria 2 & 64.17 & 26.67 & 314.1 \\
Aswan & 71.83 & 23.33 & 303.4 \\
Beheira 1 & 71.00 & 23.83 & 393.8 \\
Beheira 2 & 61.33 & 23.67 & 384.1 \\
Beheira 3 & 92.17 & 26.67 & 435.9 \\
Beheira 4 & 94.00 & 25.50 & 360.4 \\
Dakahlia 1 & 70.17 & 25.17 & 284.0 \\
Dakahlia 2 & 66.00 & 23.00 & 248.6 \\
Dakahlia 3 & 76.50 & 23.50 & 273.1 \\
Eskandarani & 76.00 & 25.33 & 330.9 \\
Gharbia 1 & 54.17 & 24.33 & 297.2 \\
Gharbia 2 & 66.00 & 24.17 & 403.4 \\
Gharbia 3 & 83.33 & 25.50 & 301.7 \\
Giza 1 & 69.67 & 26.33 & 445.7 \\
Giza 2 & 71.67 & 23.17 & 356.8 \\
Matruh 1 & 101.50 & 28.67 & 281.4 \\
Matruh 2 & 76.50 & 26.00 & 318.0 \\
North Sinai & 73.67 & 24.83 & 384.5 \\
Sohag & 81.33 & 22.00 & 208.8 \\
L.S.D. 0.05 & 2.68 & 1.21 & 8.98 \\
\hline
\end{tabular}

Table 3. The growth habit, branching, and degree of branching of squash landraces by using UPOV descriptors in the combined two seasons of 2012 and 2013.

\begin{tabular}{|c|c|c|c|c|c|c|c|c|c|c|}
\hline & & Growth $\mathrm{h}$ & bit & Bran & ching & & De & ree of Brar & ching & \\
\hline Landraces & Bush & $\begin{array}{l}\text { Semi- } \\
\text { trailing }\end{array}$ & Trailing & Absent & Present & $\begin{array}{l}\text { Very } \\
\text { Weak }\end{array}$ & Weak & Medium & Strong & $\begin{array}{l}\text { Very } \\
\text { Strong }\end{array}$ \\
\hline Alexandria 1 & + & - & - & - & + & + & - & - & - & - \\
\hline Alexandria 2 & - & + & - & - & + & - & - & + & - & - \\
\hline Aswan & - & + & - & - & + & - & - & + & - & - \\
\hline Beheira 1 & - & + & - & - & + & - & + & - & - & - \\
\hline Beheira 2 & + & - & - & + & - & - & - & - & - & - \\
\hline Beheira 3 & - & + & - & + & - & - & - & - & - & - \\
\hline Beheira 4 & - & + & - & - & + & - & - & - & + & - \\
\hline Dakahlia 1 & + & - & - & + & - & - & - & - & - & - \\
\hline Dakahlia 2 & + & - & - & + & - & - & - & - & - & - \\
\hline Dakahlia 3 & + & - & - & - & + & - & + & - & - & - \\
\hline Eskandarani & & + & - & + & - & - & - & - & - & - \\
\hline Gharbia 1 & + & - & - & + & - & - & - & - & - & - \\
\hline Gharbia 2 & + & - & - & + & - & - & - & - & - & - \\
\hline Gharbia 3 & - & + & - & - & + & - & + & - & - & - \\
\hline Giza 1 & - & + & - & + & & - & - & - & - & - \\
\hline Giza 2 & - & + & - & - & + & - & - & + & - & - \\
\hline Matruh 1 & - & + & - & - & + & - & + & - & - & - \\
\hline Matruh 2 & + & - & - & - & + & - & + & - & - & - \\
\hline North Sinai & - & - & + & - & + & - & - & + & - & - \\
\hline Sohag & + & - & - & + & - & - & - & - & - & - \\
\hline No. \# & 9 & 10 & 1 & 9 & 11 & 1 & 5 & 4 & 1 & 0 \\
\hline$\%$ & 45 & 50 & 5 & 45 & 55 & 5 & 25 & 20 & 5 & 0 \\
\hline
\end{tabular}


Table 4. The stem color, intensity of stem green color, mottling, tendrils and leaf blade size of squash landraces by using UPOV descriptors in the two combined seasons of 2012 and 2013.

\begin{tabular}{|c|c|c|c|c|c|c|c|c|c|c|c|c|c|c|c|c|}
\hline \multirow[b]{2}{*}{ Landraces } & \multicolumn{2}{|c|}{ Stem Color } & \multicolumn{5}{|c|}{ Intensity of stem green color } & \multicolumn{2}{|c|}{ Mottling } & \multicolumn{2}{|c|}{ Tendrils } & \multicolumn{5}{|c|}{ Leaf Blade Size } \\
\hline & Green & $\begin{array}{c}\text { Partly green \& } \\
\text { partly yellow }\end{array}$ & $\begin{array}{l}\text { Very } \\
\text { Light }\end{array}$ & Light & Medium & Dark & $\begin{array}{l}\text { Very } \\
\text { Dark }\end{array}$ & Absent & Present & $\begin{array}{l}\text { Absent to } \\
\text { rudimentary }\end{array}$ & $\begin{array}{c}\text { Well } \\
\text { developed }\end{array}$ & $\begin{array}{l}\text { Very } \\
\text { small }\end{array}$ & Small & Medium & Large & $\begin{array}{l}\text { Very } \\
\text { Large } \\
\end{array}$ \\
\hline Alexandria 1 & + & - & - & - & + & - & - & + & - & - & + & - & - & - & - & + \\
\hline Alexandria 2 & + & - & - & - & & + & - & + & - & - & + & - & - & + & - & - \\
\hline Aswan & + & - & - & - & + & - & - & + & - & - & + & - & - & - & - & + \\
\hline Beheira 1 & - & + & - & - & - & + & - & + & - & - & + & - & - & - & + & - \\
\hline Beheira 2 & + & - & - & + & - & - & - & + & - & - & + & - & - & - & - & + \\
\hline Beheira 3 & - & + & + & & - & - & - & + & - & - & + & - & - & + & - & - \\
\hline Beheira 4 & - & + & - & + & - & - & - & - & + & - & + & - & + & - & - & - \\
\hline Dakahlia 1 & + & - & - & - & - & + & - & + & - & - & + & - & - & - & + & - \\
\hline Dakahlia 2 & + & - & - & - & - & + & - & + & - & - & + & - & - & + & - & - \\
\hline Dakahlia 3 & + & - & - & - & + & - & - & + & - & - & + & - & - & - & + & - \\
\hline Eskandarani & + & - & - & - & - & + & - & - & + & - & + & - & - & - & + & - \\
\hline Gharbia 1 & + & - & - & - & - & + & - & + & - & + & - & - & - & + & - & - \\
\hline Gharbia 2 & - & + & + & - & - & - & - & + & - & - & + & - & - & - & - & + \\
\hline Gharbia 3 & + & - & - & + & - & - & - & + & - & + & - & - & + & - & - & - \\
\hline Giza 1 & + & - & - & + & - & - & - & + & - & - & + & - & - & - & - & + \\
\hline Giza 2 & + & - & - & - & + & - & - & + & - & + & - & - & - & - & + & - \\
\hline Matruh 1 & + & - & - & - & - & + & - & + & - & - & + & - & - & + & - & - \\
\hline Matruh 2 & + & - & - & - & - & + & - & + & - & + & - & - & - & + & - & - \\
\hline North Sinai & - & + & + & - & - & - & - & + & - & - & + & - & - & - & + & - \\
\hline Sohag & + & - & - & - & - & + & - & + & - & + & - & - & - & + & - & - \\
\hline No. \# & 15 & 5 & 3 & 4 & 4 & 9 & 0 & 18 & 2 & 5 & 15 & 0 & 2 & 7 & 6 & 5 \\
\hline$\%$ & 75 & 25 & 15 & 20 & 20 & 45 & 0 & 90 & 10 & 25 & 75 & 0 & 10 & 35 & 30 & 25 \\
\hline
\end{tabular}

Table 5. Leaf incisions, leaf green color intensity, silvery patches and relative area covered by silvery patches of the squash landraces by using UPOV descriptors in the two combined seasons of 2012 and 2013.

\begin{tabular}{|c|c|c|c|c|c|c|c|c|c|c|c|c|c|c|c|}
\hline \multirow[b]{2}{*}{ Landraces } & \multicolumn{5}{|c|}{ Leaf incisions } & \multicolumn{3}{|c|}{$\begin{array}{l}\text { Leaf green color } \\
\text { intensity }\end{array}$} & \multicolumn{2}{|c|}{ Silvery patches } & \multicolumn{5}{|c|}{$\begin{array}{c}\text { Relative area covered by silvery } \\
\text { patches }\end{array}$} \\
\hline & $\begin{array}{l}\text { Absent or very } \\
\text { shallow }\end{array}$ & Shallow & Medium & Deep & $\begin{array}{l}\text { Very } \\
\text { Deep }\end{array}$ & Light & Medium & Dark & Absent & Present & $\begin{array}{l}\text { Very } \\
\text { small }\end{array}$ & Small & Medium & Large & $\begin{array}{l}\text { Very } \\
\text { Large }\end{array}$ \\
\hline Alexandria 1 & + & - & - & - & - & - & - & + & + & - & - & - & - & - & - \\
\hline Alexandria 2 & - & - & + & - & - & - & - & + & + & - & - & - & - & - & - \\
\hline Aswan & + & - & - & - & - & - & - & + & + & - & - & - & - & - & - \\
\hline Beheira 1 & - & - & + & - & - & + & - & - & + & - & - & - & - & - & - \\
\hline Beheira 2 & + & - & - & - & - & - & + & - & - & + & - & + & - & - & - \\
\hline Beheira 3 & - & - & + & - & - & - & + & - & + & - & - & - & - & - & - \\
\hline Beheira 4 & - & - & - & - & + & - & - & + & + & - & - & - & - & - & - \\
\hline Dakahlia 1 & - & - & + & - & - & - & - & + & + & - & - & - & - & - & - \\
\hline Dakahlia 2 & - & - & - & + & - & - & - & + & - & + & - & - & - & + & - \\
\hline Dakahlia 3 & - & + & - & - & - & - & + & - & + & - & - & - & - & - & - \\
\hline Eskandarani & - & & + & - & - & - & + & - & + & - & - & - & - & - & - \\
\hline Gharbia 1 & - & + & - & - & - & - & + & - & + & - & - & - & - & - & - \\
\hline Gharbia 2 & + & - & - & - & - & - & + & - & + & - & - & - & - & - & - \\
\hline Gharbia 3 & - & + & - & - & - & - & + & - & + & - & - & - & - & - & - \\
\hline Giza 1 & - & + & - & - & - & - & + & - & + & - & - & - & - & - & - \\
\hline Giza 2 & - & + & - & - & - & - & + & - & + & - & - & - & - & - & - \\
\hline Matruh 1 & - & + & - & - & - & - & + & - & + & - & - & - & - & - & - \\
\hline Matruh 2 & - & + & - & - & - & - & + & - & + & - & - & - & - & - & - \\
\hline North Sinai & - & - & + & - & - & - & + & - & + & - & - & - & - & - & - \\
\hline Sohag & - & - & - & - & + & - & - & + & - & + & - & - & + & - & - \\
\hline No. \# & 4 & 7 & 6 & 1 & 2 & 1 & 12 & 7 & 17 & 3 & 0 & 1 & 1 & 1 & 0 \\
\hline$\%$ & 20 & 35 & 30 & 5 & 10 & 5 & 60 & 35 & 85 & 15 & 0 & 5 & 5 & 5 & 0 \\
\hline
\end{tabular}


Table 6. The petiole length, attitude of petioles and prickles number of the various squash landraces by using UPOV descriptors in the two combined seasons of 2012 and 2013.

\begin{tabular}{|c|c|c|c|c|c|c|c|c|c|c|c|c|c|}
\hline & \multicolumn{3}{|c|}{ Petiole length } & \multicolumn{5}{|c|}{ Attitude of petioles } & \multicolumn{5}{|c|}{ Number of prickles } \\
\hline Landraces & Short & Medium & Long & Erect & $\begin{array}{l}\text { Erect to semi- } \\
\text { erect }\end{array}$ & Semi-erect & $\begin{array}{c}\text { Semi-erect to } \\
\text { horizontal }\end{array}$ & Horizontal & $\begin{array}{c}\text { Absent or very } \\
\text { few }\end{array}$ & Few & Medium & Many & Very Many \\
\hline Alexandria 1 & - & - & + & - & + & - & - & - & - & - & - & + & - \\
\hline Alexandria 2 & - & + & & - & + & - & - & - & - & - & + & & - \\
\hline Aswan & - & - & + & - & + & - & - & - & - & - & - & + & - \\
\hline Beheira 1 & + & - & - & - & - & + & - & - & - & + & - & - & - \\
\hline Beheira 2 & - & - & + & - & - & - & + & - & - & - & - & - & + \\
\hline Beheira 3 & - & - & + & - & - & - & + & - & - & + & - & - & - \\
\hline Beheira 4 & + & - & - & + & - & - & - & - & - & - & - & + & - \\
\hline Dakahlia 1 & - & - & + & - & + & - & - & - & - & + & - & - & - \\
\hline Dakahlia 2 & + & - & - & - & - & - & + & - & - & + & - & - & - \\
\hline Dakahlia 3 & - & + & - & - & - & + & - & - & + & - & - & - & - \\
\hline Eskandarani & - & - & + & - & + & - & - & - & - & - & + & - & - \\
\hline Gharbia 1 & - & + & - & & + & - & - & - & - & - & - & + & - \\
\hline Gharbia 2 & - & + & - & + & - & - & - & - & - & - & + & - & - \\
\hline Gharbia 3 & + & - & - & & - & - & + & - & - & - & - & + & - \\
\hline Giza 1 & - & - & + & + & - & - & - & - & - & - & - & + & - \\
\hline Giza 2 & - & + & - & - & + & - & - & - & - & + & - & - & - \\
\hline Matruh 1 & + & - & - & - & - & + & - & - & - & + & - & - & - \\
\hline Matruh 2 & + & - & - & + & - & - & - & - & - & - & + & - & - \\
\hline North Sinai & - & - & + & - & - & - & + & - & - & + & - & - & - \\
\hline Sohag & + & - & - & - & - & - & + & - & - & + & - & - & - \\
\hline No.\# & 7 & 5 & 8 & 4 & 7 & 3 & 6 & 0 & 1 & 8 & 4 & 6 & 1 \\
\hline$\%$ & 35 & 25 & 40 & 20 & 35 & 15 & 30 & 0 & 5 & 40 & 20 & 30 & 5 \\
\hline
\end{tabular}

Table 7. The characterization of the female flower characteristics of the various squash landraces by using UPOV descriptors in the two combined seasons of 2012 and 2013.

\begin{tabular}{lccccccc}
\hline & Inner side ring in Corolla & \multicolumn{3}{c}{ Color of inner side ring } & \multicolumn{2}{c}{ Intensity of color of green ring } \\
\hline \multicolumn{1}{c}{ Landraces } & Absent & Present & Yellow & Green & Yellow \& Green & Weak & Medium \\
\hline Alexandria 1 & + & - & - & - & - & - & - \\
Alexandria 2 & + & - & - & - & - & - & - \\
Aswan & - & + & - & + & - & - & - \\
Beheira 1 & - & + & + & - & - & - & - \\
Beheira 2 & - & + & - & + & - & - & - \\
Beheira 3 & + & - & - & - & - & - & - \\
Beheira 4 & + & - & - & - & - & - & - \\
Dakahlia 1 & - & + & - & + & - & - & - \\
Dakahlia 2 & - & + & - & + & - & - & + \\
Dakahlia 3 & - & + & - & + & - & - & - \\
Eskandarani & - & + & + & - & - & - \\
Gharbia 1 & - & + & - & + & - & - \\
Gharbia 2 & + & - & - & - & - & - \\
Gharbia 3 & - & + & - & + & - & - & + \\
Giza 1 & - & + & + & - & - & - \\
Giza 2 & - & + & - & + & - & - \\
Matruh 1 & - & + & + & - & - & - \\
Matruh 2 & + & - & - & - & - & - \\
North Sinai & - & + & + & - & - & - \\
Sohag & - & + & - & + & - & - & - \\
No. \# & 6 & 14 & 5 & 9 & - & - \\
\% & 30 & 70 & 25 & 45 & 0 & - & - \\
\hline
\end{tabular}


Table 8. The characterization of the male flower characteristics of the various squash landraces by using UPOV descriptors in the two combined seasons of 2012 and 2013.

\begin{tabular}{|c|c|c|c|c|c|c|c|c|}
\hline \multirow[b]{2}{*}{ Landraces } & \multicolumn{2}{|c|}{ Inner side ring in Corolla } & \multicolumn{3}{|c|}{ Color of inner side ring } & \multicolumn{3}{|c|}{ Intensity of color of green ring } \\
\hline & Absent & Present & Yellow & Green & Yellow \& Green & Weak & Medium & Strong \\
\hline Alexandria 1 & - & + & - & + & - & + & - & - \\
\hline Alexandria 2 & - & + & - & + & - & + & - & - \\
\hline Aswan & - & + & - & + & - & + & - & - \\
\hline Beheira 1 & - & + & + & - & - & - & - & - \\
\hline Beheira 2 & + & - & - & - & - & - & - & - \\
\hline Beheira 3 & + & - & - & - & - & - & - & - \\
\hline Beheira 4 & + & - & - & - & - & - & - & - \\
\hline Dakahlia 1 & - & + & - & + & - & + & - & - \\
\hline Dakahlia 2 & - & + & - & + & - & - & - & + \\
\hline Dakahlia 3 & + & & - & - & - & - & - & - \\
\hline Eskandarani & - & + & - & + & - & - & + & - \\
\hline Gharbia 1 & - & + & - & + & - & - & - & + \\
\hline Gharbia 2 & - & + & + & - & - & - & - & - \\
\hline Gharbia 3 & + & - & - & - & - & - & - & - \\
\hline Giza 1 & - & + & - & + & - & + & - & - \\
\hline Giza 2 & - & + & - & + & - & + & - & - \\
\hline Matruh 1 & - & + & + & - & - & - & - & - \\
\hline Matruh 2 & - & + & + & - & - & - & - & - \\
\hline North Sinai & + & - & - & - & - & - & - & - \\
\hline Sohag & + & - & - & - & - & - & - & - \\
\hline No.\# & 7 & 13 & 4 & 9 & 0 & 6 & 1 & 2 \\
\hline$\%$ & 35 & 65 & 20 & 45 & 0 & 30 & 5 & 10 \\
\hline
\end{tabular}

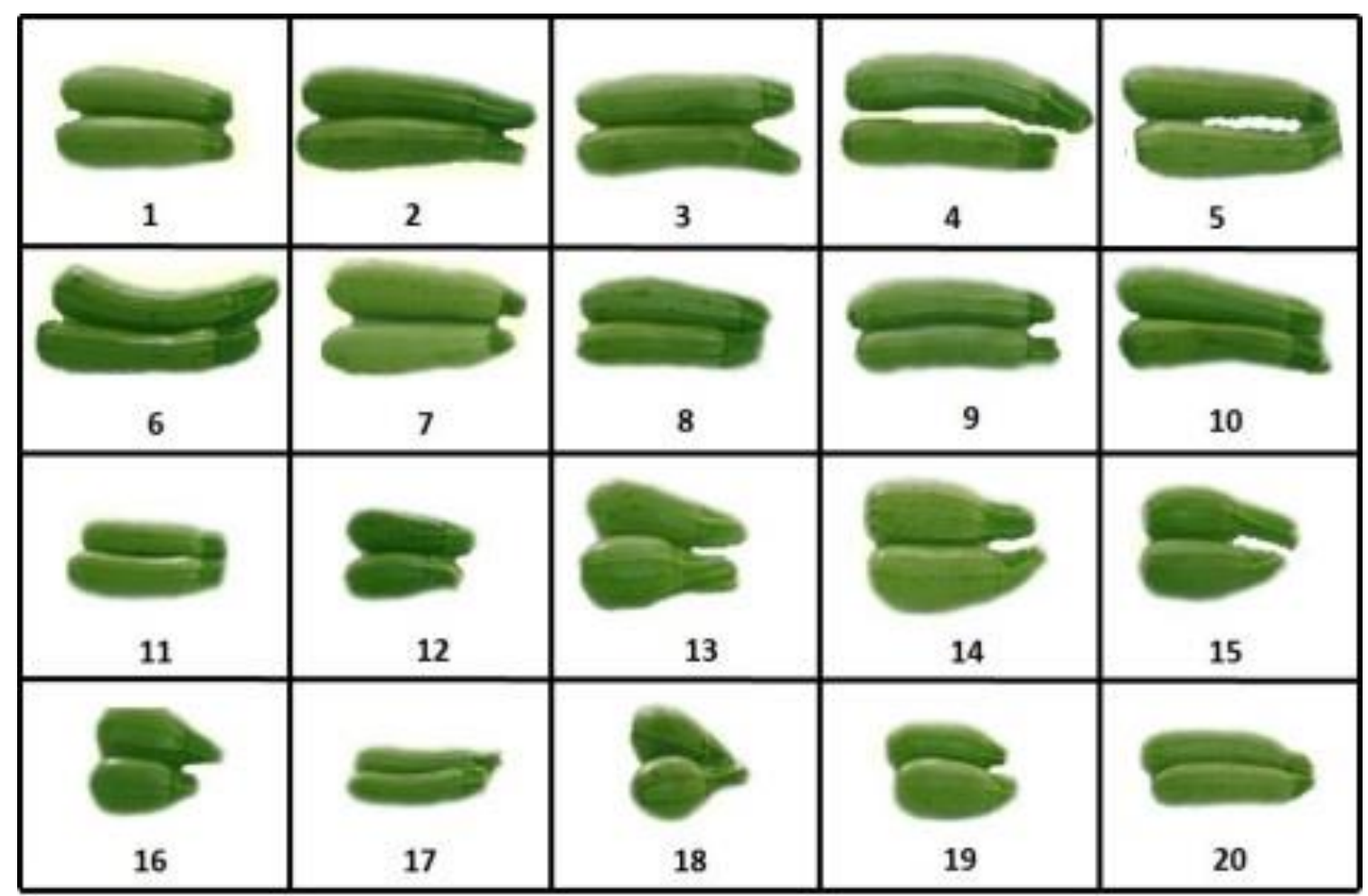

Figure 1: The morphological traits of 20 squash landraces fruit (Cucurbita pepo, L.). 


\title{
توصيف سلالات قرع الكوسة باستخدام واصفات اليوبوف والصفات المورفولوجية
}

\author{
عماد ماضي 1,2، لايل كيكر 33، علاء الدين هلالي 1,"

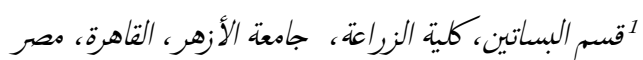

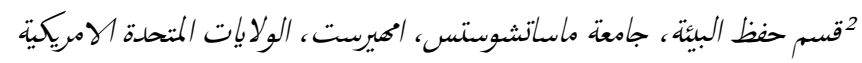

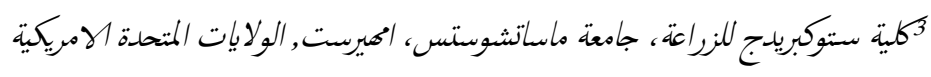 \\ البريد الاككترونى للباحث الرئيس: alaahelaly@azhar.edu.eg
}

الملخص العربي

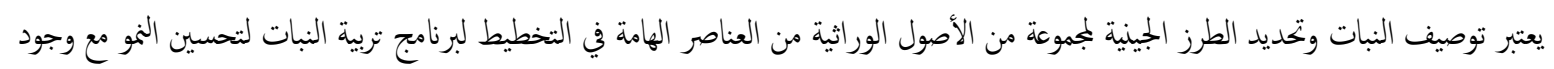

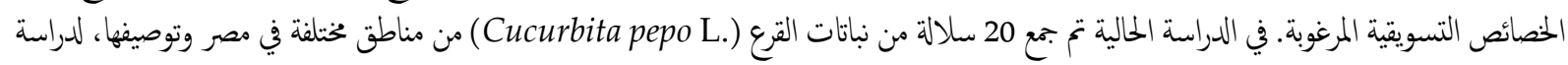

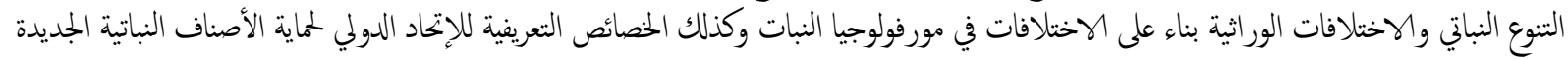
(UPOV)

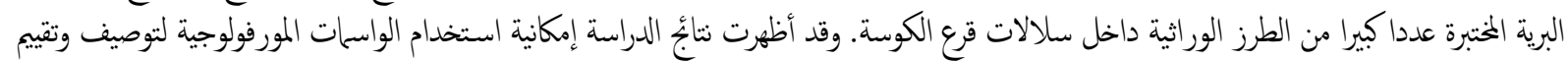

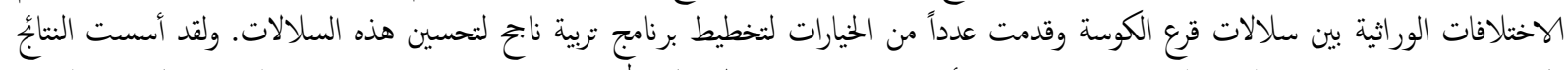

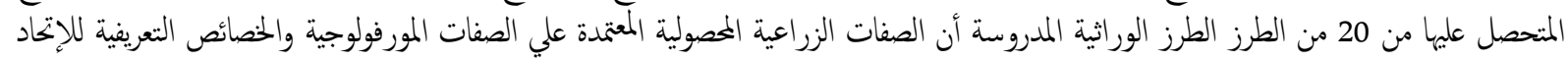

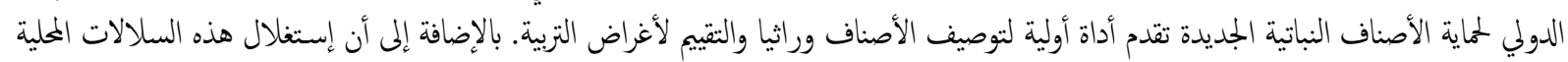

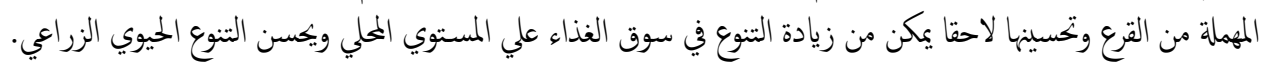
الكلمات الاسترشادية: قرع الكوسة، اليوبوف، التنوع الجيني، السلالات المحلية. 